\title{
O GÊNERO NO JUÍZO DOS ÓRFÃOS DE PORTO ALEGRE ${ }^{1}$ THE GENDER IN JUÍZO DOS ÓRFÃOS OF PORTO ALEGRE
}

\author{
José Carlos da Silva Cardozo*
}

\begin{abstract}
Resumo: Pesquisar a família porto-alegrense, no início do século XX, tendo por meio a Justiça é refletir sobre a relação dos papeis sexuais socialmente construídos e as relações de poder. Os sujeitos que pleiteavam a guarda de um menor de idade se apropriavam das concepções de gênero para disputar essa criança ou adolescente na Justiça. Este texto, à luz da História Social, procura identificar como que se apresentavam essas relações nos processos judiciais de tutela, abertos nos anos de 1900 a 1927, na cidade de Porto Alegre. Dessa forma, evidenciando a situação delicada que a mulher adulta tinha perante o homem adulto quando decidia pleitear a tutela de uma criança ou adolescente e a preocupação que Justiça e sociedade tinham para com as meninas.
\end{abstract}

Palavras-chave: Gênero. Juízo dos Órfãos. Porto Alegre.

\begin{abstract}
Research family porto-alegrense, in the early twentieth century, through the courts is to reflect on the relationship between socially constructed genus roles. The gender was present in court and, therefore, used by the subjects who were claiming the custody of a minor. This text, in light of Social History, which seeks to identify how these relationships presented in court proceedings for tutelage, opened in the years 1900 to 1927, in Porto Alegre city. Thus, highlighting the delicate situation that the woman before the man had decided to plead when the tutelage of a child or adolescent and the concern that justice and society had for the girls.
\end{abstract}

Keywords: Gender. Juízo dos Órfãos. Porto Alegre.

* Doutorando no Programa de Pós-Graduação em História Latino-Americana da Universidade do Vale do Rio dos Sinos (UNISINOS). Bolsista da CAPES.

E-mail: jcs.cardozo@gmail.com 
A passagem do século XIX para o XX foram anos de grande otimismo para a sociedade brasileira; um novo século calcado no progresso ditava o tom da expectativa que homens, mulheres e crianças estavam a sentir. O fim da escravidão, a República e a crescente industrialização traziam grande júbilo à nação brasileira que com os olhos voltados para o "velho continente" e os Estados Unidos da América, aspiravam se tornar, já no início do século XX, um país moderno, respeitado e admirado pelas outras nações.

Contudo, para que isso fosse possível, havia a necessidade, por parte dos grupos dirigentes, de se alterar hábitos e costumes da população, apagando por completo o passado colonial e imperial brasileiro. Dessa forma, este texto investiga as relações de gênero desenvolvidas no campo jurídico por meio dos processos de tutela de menores de idade ${ }^{2}$, na cidade de Porto Alegre, nos anos iniciais do século XX. Em estudos anteriores já refletimos sobre a figura da menina e da mulher em relação com a Justiça, mas não de forma sistemática e com o foco exclusivo na relação entre os papéis sexuais socialmente construídos ${ }^{3}$, bem como nas relações de poder ${ }^{4}$ advindas desta. Assim, não é retórico o uso do termo gênero neste texto, pois estamos justamente fugindo do determinismo biológico da figura da menina ou mulher, uma diferença sexual em relação ao menino e homem, para reconhecer que se trata de uma diferença social, cultural e de poder, diferença que se refletia na Justiça. ${ }^{5}$

Há mais de cinco anos, tenho a oportunidade de dedicar-me à investigação do Juízo dos Órfãos em Porto Alegre e neste período, tendo por foco mais de 80 anos da atuação dessa instituição na capital do Rio Grande do Sul (meados do século XIX até meados do século XX), tomando como fonte principal de estudo os processos judiciais de tutela ${ }^{6}$ de menores de idade, percebemos a desvalorização que a mulher recebia da sociedade e, consequentemente, do Judiciário quando esta comparecia perante a Justiça com a finalidade de receber a guarda de uma criança, adolescente ou jovem e a grande preocupação e valorização que as menores de idade recebiam por parte da sociedade e do Judiciário.

O Juízo dos Órfãos foi uma instituição portuguesa, decorrente das Ordenações Filipinas ${ }^{7}$, código jurídico a partir de 1580 do Império Luso, que tinha por obrigação zelar por todos os menores de idade, cuidando de sua pessoa, mas a atenção do Juízo recaia principalmente para os menores oriundos das famílias de elite (aquelas que possuíam legados a deixar). Com o passar do tempo, essa instituição do Judiciário foi ampliando sua ação, direcionando sua atenção também para os menores não pertencentes às famílias das elites. No Brasil, especialmente a partir da formulação das leis "antiescravistas". No ano de 1871, a Lei do Ventre Livre ${ }^{8}$ instituiu que as crianças nascidas de ventre escravo, a partir daquele ano, seriam consideradas ingênuas e não mais escravas, ficando, assim, "livres" do jugo senhoril e, em 1888, pela promulgação da Abolição, houve a libertação por completo dos escravos de seus antigos 
senhores. Com essas e outras medidas que visavam à lenta liberdade do cativeiro, houve a necessidade do contingente de escravos e ex-escravos ser direcionado para o trabalho assalariado'; uma nova ética do trabalho deveria ser internalizada em todos os indivíduos; mas, para isso, hábitos e costumes da população deveriam ser alterados para o padrão que os grupos dirigentes estavam a impor.

Porto Alegre sempre esteve em consonância com as diretrizes centrais do governo, pois, desde 1806, já havia Juízo de Órfãos e esta instituição transpôs o período colonial chegando até a República, quando houve a criação em 1927 e a substituição em definitivo, na capital do Rio Grande do Sul, deste pelo Juizado de Menores em 1933.

Assim, o Juízo dos Órfãos foi, desde o período Colonial até o início da República, uma das instituições mais importantes para a regularização das questões relativas à família e à criança, essa instituição cuidou, num primeiro momento, dos menores das elites, na resolução não só de questões envolvendo suas heranças, da relação entre os menores e seus familiares ou tutores, como também de outras que diziam respeito à sua renda e a seus bens. Após, com a formação de novas relações sociais, tornaram esses indivíduos as figuras centrais no espaço familiar, pois as crianças e os adolescentes seriam os futuros cidadãos e cidadãs da República brasileira.

A presente reflexão pretende analisar como que as relações de gênero são apresentadas nos processos de tutela do Juízo dos Órfãos de Porto Alegre nos anos de 1900-1927, espaço privilegiado para compreendermos as relações sociais e de poder que circundavam homens e mulheres nos anos iniciais do século XX, assim como a participação das mulheres nos processos judiciais de guarda de crianças e adolescentes.

\section{HISTÓRIAS PARECIDAS OU DECISÕES PRESUMÍVEIS?}

No dia 21 de setembro de 1915, o sargento do exército, A. Q. do R. ${ }^{10}$, entrou com um pedido para resgatar seu filho, E. ${ }^{11}$, de três anos e três meses de idade, no $3^{\circ}$ Cartório do Juízo de Órfãos de Porto Alegre, contra sua esposa L. da S. R. com quem se encontrava a criança.

O que estava acontecendo? Por que o marido entrou com um processo contra sua própria esposa?

A. Q. do R. já não morava com L. da S. R. havia mais de um mês e, em virtude da separação, queria a guarda de seu filho. O pai da criança não desejava que o menino fosse educado por sua mulher, que, conforme suas alegações, tinha "vida irregular", ou mesmo por sua sogra e suas duas cunhadas, que eram de "vida também duvidosa"12, como faz questão de enfatizar em sua petição. Todas elas, L. da S. R., sua mãe e irmãs, viviam juntas na Rua João Alfredo ${ }^{13}$, número 141. 
Nota-se que havia problemas na relação entre o suplicante e sua esposa, mas os detalhes destes não ficaram registrados no processo, não sendo aprofundados nem por parte do marido, nem por parte de sua mulher. Acrescente-se que ambos não estavam separados judicialmente, conforme depreendemos da fonte consultada, mantendo, dessa maneira, os vínculos matrimoniais.

No entanto, nesse momento, o que nos interessa - e que é o cerne desse processo - não são os motivos que levaram A. Q. do R. ao Judiciário, nem mesmo a situação civil de nossos atores sociais, mas, sim, analisar a atuação dos juristas que trabalharam no caso.

No mesmo dia da abertura do processo, o Juiz determinado para acompanhar os trâmites foi H. T. O Juiz designado pede, então, vistas ${ }^{14}$ ao Curador Geral de Órfãos ${ }^{15}$, Doutor A. P., que, no dia seguinte, dá o parecer sobre o caso em tela.

No referido parecer, e dado que A. Q. do R. e L. da S. R. ainda se encontravam legalmente casados, o Curador Geral de Órfãos argumenta que, somente após a separação oficial dos cônjuges será possível determinar com quem ficará a guarda do filho menor. Sua decisão teve por base o Decreto 181, de 1890, artigo número 90 que, com relação ao divórcio, estabelecia que, com "a sentença do divórcio litigioso, mandará entregar os filhos comuns e menores ao cônjuge inocente e fixará a quota com que o culpado deverá concorrer com a educação deles".

Afirmava ainda que a aplicação do dispositivo acima somente poderia ser utilizada na sentença proferida em divórcio amigável ou litigioso. ${ }^{16}$ Dessa forma, tendo em vista que não havia sido procedida a separação legal ou a comprovação desse fato, o Curador Geral opinava pelo indeferimento do pedido do solicitante A. Q. do R.

Entretanto, o Juiz H. T. não compartilhou da mesma opinião do Curador Geral. No dia vinte e quatro do mesmo mês, emite sua decisão reportando ao fato que, se o pai ainda continuava casado legalmente com a mãe da criança, na "vigência do casamento, o pátrio poder e, consequentemente, a posse e

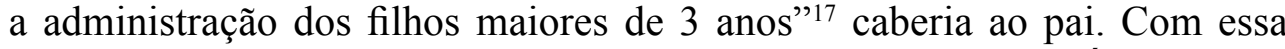
decisão, que contrariava a interpretação do Curador Geral de Órfãos, pela qual o menor deveria continuar com sua mãe, o Juiz mandou que o Oficial de Justiça executasse a decisão de busca e apreensão do menor E. e o entregasse ao seu pai, o sargento do exército A. Q. do R. Nesse mesmo dia, o oficial A. P. da R. fez a apreensão do menor E. na casa de L. da S. R. e o entregou ao pai da criança.

O processo do menor E. é exemplar para refletirmos sobre um tema fundamental, que é o da interpretação dada pelos juristas sobre os casos que eram encaminhados ao Juízo dos Órfãos, tendo o seu desfecho definido a partir da decisão de seus membros. No exemplo do caso arrolado, o Juiz não 
fez ou requisitou qualquer investigação sobre a pessoa do pai do menor ou a respeito da veracidade das afirmações deste, ou mesmo do tratamento dado ao menor por sua mãe, avó ou tias. Usando de suas atribuições, que lhe davam autonomia e independência, o Juiz interpretou, arbitrou e aplicou, de acordo com suas convicções, o que a lei regulamentava sobre a posse da criança, de forma direta.

Em outro caso, o empregado da Companhia de Energia Força e Luz, M. J. C. entrou, em quinze de março de 1916, com um processo semelhante ao de A. Q. do R., requerendo a entrega de sua filha, J. ${ }^{18}$ de "quase dois anos" de idade, que se achava em posse de sua esposa L. M. da T.

Casados legalmente desde 23 de março de 1913, dizia M. J. C. que havia "um mês mais ou menos" estava afastado de sua mulher. A separação havia decorrido do fato de M. J. C. ter ido morar com sua mãe, M. F. da C., na Rua Miguel Teixeira ${ }^{19}$, número 6 . De acordo com o que se depreende do processo, em princípio, parece que sogra e nora não se davam muito bem. Pelo menos essa era a alegação de M. J. C. e, devido a esse "pretexto", marido e mulher se separaram.

A fonte compulsada ainda nos informa que L. M. da T. continuou morando no antigo endereço do casal que se situava a algumas dezenas de metros adiante, no número 9, da mesma rua em que a sogra residia. Em outras palavras, a documentação nos revela que, de fato, ambas viviam na mesma vizinhança, em locais muito próximos.

Esse processo, apresentado ao Juízo dos Órfãos, ainda introduz uma quarta figura, B. de O. C., "homem solteiro", que, segundo consta, já morava com o casal antes da separação. A inclusão desse nome, que só vem à tona na alegação do pai da menor, não foi dada ao acaso. De acordo com os padrões sociais e morais vigentes nos anos iniciais do século XX, era embaraçoso e, no mínimo, suspeito e constrangedor para uma mulher separada viver, sob o mesmo teto, com um "homem solteiro". Assim, com essa declaração, M. J. C. atingia diretamente a honra de sua esposa.

Com base nesse(s) "irregular[es] procedimento[s]"20 de L. M. da T., que não quis acompanhar seu marido e insistiu em continuar vivendo sob o mesmo teto com um "homem solteiro", esta incorria em um comportamento pouco adequado, pois, segundo as alegações de seu marido, além de estar "atirada completamente na prostituição", acrescentava que sua filha, de quase dois anos de idade, estaria "sofrendo as consequências da péssima existência que leva a mãe pelo nocivo caminho em que [se] enredou". Sem dúvida, essas alegações tinham a intenção de sensibilizar, definitivamente, o Juiz encarregado de tratar do caso.

Nas páginas que compõem o processo, M. J. C. afirmava que queria cuidar da menina J., educar a pequena e "assegurar-lhe o futuro". Para mais, adiantava que, quando recebesse sua filha, esta seria "confiada aos cuidados 
de sua mãe"21, com quem dividia o mesmo teto. Com o intuito de confirmar o fato de ser casado com a ré e de ser pai da menor, o suplicante anexou ao processo às respectivas certidões de casamento e de nascimento.

No mesmo dia da abertura do processo, o Juiz Doutor J. S. pede vistas ao Curador Geral dos Órfãos Doutor A. P. (o mesmo do processo anterior). Ao receber o processo, no mesmo dia, o Curador Geral emitiu seu parecer, que transcrevemos abaixo, em sua íntegra:

Em vista da certidão de folhas cinco [Certidão de Nascimento], constitutiva da prova de que J. é menor de dois anos, atendendo o estabelecido no art. 96 do Dec. 181 de 24 de janeiro de 1890, outorgando à mãe, em qualquer caso, a faculdade de conservar consigo os filhos até a idade de 3 anos, sem distinção de sexo, opino pelo indeferimento da petição retro. ${ }^{22}$

Dessa forma, o Curador Geral de Órfãos deixa claro que a mãe da menor deverá continuar com a guarda de sua filha.

Será que as alegações do pai não foram suficientes para que o Juízo dos Órfãos avaliasse a situação e julgasse as acusações em favor dele? Será que esse processo é um caso "especial”" em que o pai, por mais que agredisse a integridade da mãe, não ficaria com a guarda da criança, com base na argumentação de que a mãe teria "em qualquer caso" a guarda de seus filhos menores de 3 anos, independente de seu comportamento frente à sociedade?

Não. Pelo que podemos constatar, a posição do Doutor J. S., Juiz do caso, foi diferente. No dia 21 de março do mesmo ano de 1916, este emitiu a seguinte decisão:

Entre as normas reguladoras da sociedade conjugal, compiladas no art. 56 do Dec. n. 181 de 24 de janeiro de 1890, compreende se ao que dá ao chefe da família o encargo de zelar a educação dos filhos e só por sua morte por ter incidido em sua incapacidade é que passa à mulher o exercício daquele poder. Assim sendo, todo e qualquer ato que importe em extinção ao exercício do pátrio poder deve ser cumpridamente provado, não se podendo impedir que o marido, como chefe da família, reclame a posse dos filhos, desde que a ele compete o patrio poder durante a vigência do casamento.

O Juiz Dr. J. S. ainda acrescenta que o parecer do Curador Geral é adequado somente nos casos em que "por efeito de sentença em ação de divórcio $\underline{\text { ou de nulidade de casamento }}^{23}$ [...] Fora destes casos, subsistindo a sociedade conjugal, não se pode negar ao marido a posse dos filhos uma vez que o assiste 
o exercício do pátrio poder". ${ }^{24}$ Com essa posição, o Juiz de Órfãos defere o pedido de entrega da menor J. ao seu pai M. J. C., o que foi realizado no dia seguinte, pelo Oficial de Justiça.

Dessa forma, por mais que a intenção do Curador Geral de Órfãos, nos dois casos, fosse de manter as crianças com suas progenitoras, ficou evidente que os Juízes de Órfãos, baseados no mesmo corpo de leis, encontravam o necessário respaldo para poder manter as crianças com o pai, privilegiando a figura masculina que integrava a antiga relação.

Ao trazer à luz esses casos, em que pese o fato de que não constituem processos de tutelas (nossa fonte principal), procuramos chamar a atenção para o fato de que nos defrontamos com posições judiciais conflitantes, as quais dificilmente aparecem nos $823^{25}$ processos de tutela abertos, entre os anos de 1900 a 1927, na cidade de Porto Alegre, por serem estes, na grande maioria dos casos, resolvidos sumariamente, sendo $81 \%$ desses deliberados em menos de 7 dias. ${ }^{26}$ Os Juízes de Órfãos tinham que administrar várias ações judiciais desde inventário até exames de sanidade. Essa sobrecarga de trabalho ocasionava a rapidez na resolução dos casos; o que num primeiro momento demonstra a preocupação da Justiça em não deixar nenhuma criança ou adolescente em situação de vulnerabilidade, também era o grande, podemos dizer, "Calcanhar de Aquiles" da instituição, já que os operadores do direito não solicitavam num primeiro momento maiores esclarecimentos sobre as alegações, somente quando havia o questionamento por uma das partes envolvidas é que também haveria uma detida averiguação dos fatos.

Para não haver o retorno do processo ao Juízo dos Órfãos e assim uma nova sobrecarga de tarefas aos juristas verificamos que, pelos dados dos 823 autos de tutoria de menores de idade, a Justiça apreciava os homens às mulheres por questões envolvendo desde aspectos financeiros até mesmo morais (condições que iremos aprofundar mais adiante) e essa situação reflete as poucas chances que as mulheres, mesmo sendo mães, tinham para disputar e receber a tutela de um menor, pois essas deveriam comprovar seu estado de "honestidade" social, por meio de testemunhos de "homens íntegros", o que alongaria os processos por período maior.

O futuro desses menores e sua formação estavam nas mãos do Juizado de Órfãos, esses pequenos eram submetidos a decisões que, muitas vezes, não levavam um dia para serem tomadas.

As crianças eram lançadas no meio de disputas que confrontam não só marido e mulher, como também envolviam avós e outros indivíduos não aparentados. Impotentes, as crianças ficavam submetidas à vontade e aos desígnios dos curadores e juízes, que decidiriam os seus destinos. ${ }^{27}$ 
As crianças eram, no início do processo, o motivo principal das ações, mas, no decorrer deste, na maioria das vezes, acabavam como figuras secundárias, sem voz, sem vontade, em que os adultos, juristas ou não, determinavam a vida presente ou futura do menor.

É notável o poder de decisão desse órgão jurídico sobre a vida de tantos menores e de suas famílias. O campo jurídico possuía em seus domínios a compreensão do que era melhor para as crianças, podendo esse menor ficar com o pai, a mãe, avós ou mesmo um desconhecido, dependendo da avaliação do Juiz. Para tornar os processos mais rápidos, os juristas não realizavam investigações mais detalhadas; a maioria dessas decisões ( $81 \%$ dos processos) eram tomadas em menos de uma semana. Somente nos casos em que houvesse a contestação da decisão do Juizado dos Órfãos é que os autos se alongavam por períodos maiores, mas, mesmo estes tinham, na maioria das vezes, seu desfecho em até um mês. Frente a este procedimento de brevidade, que agilizava a responsabilidade sobre a guarda de um menor, temos um padrão de atuação favorável aos homens.

Dessa forma, nota-se que havia uma práxis pelos tutores do sexo masculino, evidenciado no Gráfico 1, demonstrando que a maioria dos tutores eram homens: dentre os 857 indivíduos, de 1900 a 1927, que receberam a tutela de um menor, 709 (83\%) eram do sexo masculino e apenas $113(13 \%)$ eram do sexo feminino.

\section{Gráfico 1 - Sexo do tutor}

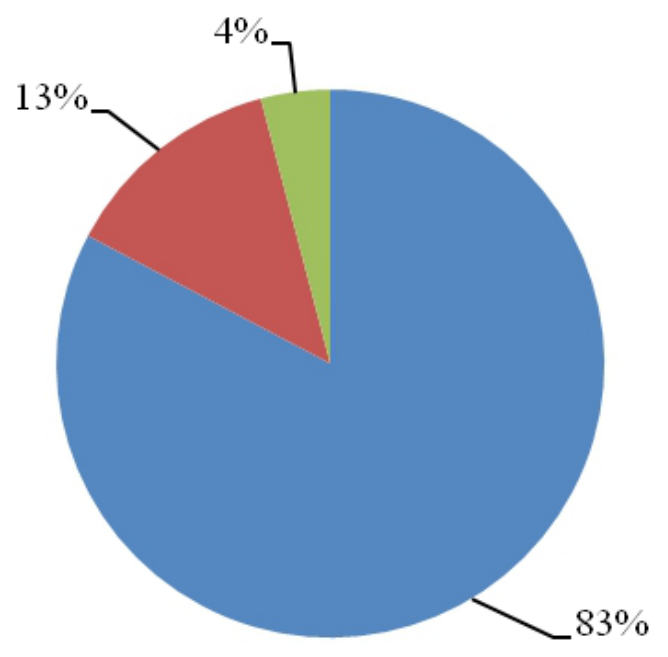

- Masculino

- Feminino

- Não declarado

Fonte: Processos de tutela de 1900 a 1927 depositados no APERS. 
Quais as razões para isso? Essa era um sociedade do tipo patriarcal: as mulheres não tinham muitas possibilidades de questionar o modelo que, de certa forma, continua vigente, de a família ser nuclear, conjugal e monogâmica. Para podermos compreender melhor os dados do Gráfico 1, é necessário perceber que no ano de 1900, a população de Porto Alegre era de 73.674 indivíduos, sendo 36.719 do sexo masculino e 36.955 do feminino; já em 1920, a cidade contava com 157.965 habitantes, sendo 75.734 do sexo masculino e 82.231 do feminino. ${ }^{28}$ Dessa forma, o Gráfico 1 indica que muito embora a população do sexo feminino estivesse crescendo mais que a do sexo masculino, a guarda de menores de idade recaia majoritariamente sobre os homens. Muitas vezes apenas interessados nos serviços das crianças e adolescentes..$^{29}$ As mulheres "independentes" não eram vistas com "bons olhos" pela sociedade, principalmente pelos grupos dirigentes. Uma mulher, solteira ou viúva, era motivo de atenção por parte de todos na espreita de um "deslize", como conseguir um emprego que acarretava sua constante circulação pela via pública, para o braço forte do Estado agir.

Os pecados imputados à mulher pelos advogados de seu marido [ou suplicante a tutor], em muitos casos, não eram mais do que a prática cotidiana da massa de trabalhadoras. $\mathrm{Na}$ realidade, temos a impressão de que se sabia dessas práticas e tolerava-as no dia-a-dia. Porém, a 'moralidade oficial' agia como arma de reserva para certas categorias de indivíduos - burgueses e/ou homens - estigmatizar outra pobres e/ou mulheres - na hora do conflito. ${ }^{30}$

As mulheres porto-alegrenses, no período em estudo, sempre estiveram em linha tênue perante a Justiça, sejam pelas Ordenações Filipinas, em que as mulheres deveriam comprovar sua condição de "honestidade" e as mães e avós, viúvas ou separadas, que pleiteassem a guarda de um filho ou neto não poderiam recasar-se ${ }^{31}$, seja com o Código Civil Brasileiro. ${ }^{32}$ Esse Código, que começa a vigorar em 1917, substituindo as Ordenações como código jurídico, e, em seu artigo 395, inciso 3, aponta que perde o pátrio poder aquele progenitor "que praticar atos contrários a moral e aos bons costumes". Mesmo que o artigo 395 ampliasse a antiga condição de vigilância para o homem, quando este era ausente nas Ordenações, continuava a valer, de forma indireta, o antigo preceito. Ainda neste mesmo código é importante ressaltar que a condição civil da mulher casada era equiparada ao dos "menores, dos silvícolas e dos alienados", em outras palavras, ela era considerada "incapaz"; determinação legal, oriunda do direito costumeiro, que ajuda a compreender o porquê que muitas mulheres não conseguiam a guarda de seu próprio filho. O caso do menor D. A. ${ }^{33}$ é um exemplo que demonstra isso: sua mãe, por haver contraído segundas núpcias, informa o Juiz J. P. de A. F. do fato e solicita um tutor para seu filho; após 
sete dias da realização do pedido, é investido o Sr. F. S. como tutor do menor D. A. Cabe acrescentar que as viúvas (mãe ou avó) que desejassem obter a tutela de um menor, deveriam ainda renunciar ao Velleano ${ }^{34}$, ou seja, mais uma complicação para as mulheres obterem a guarda.

Nas disputas entre homem e mulher pela guarda de uma criança ou adolescente no Juízo dos Órfãos de Porto Alegre, os primeiros, na grande maioria das vezes, eram preferidos pela Justiça. As poucas mulheres que conseguiram a guarda de um menor de idade eram avós que tinham a condição de viúvas; mas houve também um número mais reduzido ainda de mães viúvas que conseguiram a guarda de seus próprios filhos. Como foi o caso da mãe $\mathrm{M}$. V. da S. que, após ficar viúva, pediu e ganhou a tutela de seu filho legítimo S. ${ }^{35}$ e dos outros três filhos do primeiro casamento do marido, após comprovar, por meio de testemunhas masculinas, que se conservava em estado de viúves e que tinha condições de cuidar dos quatro menores de idade. Caso semelhante ao da viúva G. B. F. que pediu e recebeu a guarda de seus sete filhos ${ }^{36}$ legítimos, com a responsabilidade de administrar os bens que seu finado marido legou para os filhos do casal.

Dos 1.290 menores que tiveram seus nomes arrolados nos processos de tutela, entre os anos de 1900 a 1927, encontramos uma preferência por menores do sexo feminino, como aponta o Gráfico 2, na proporção de 55\% (711 meninas).

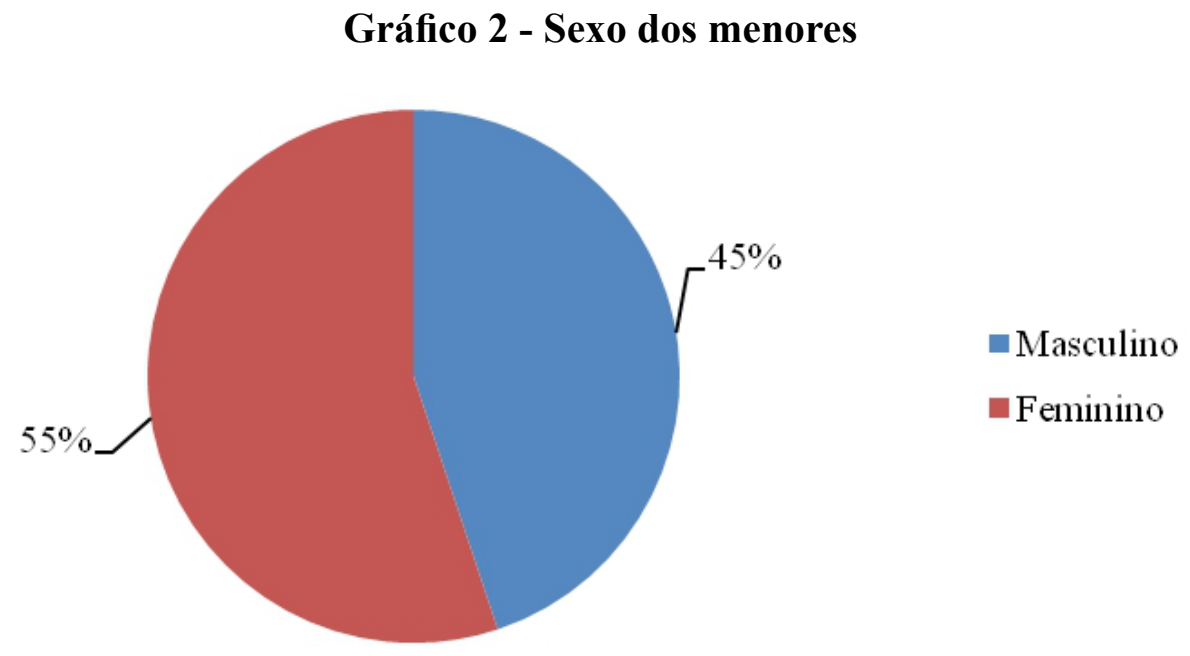

Fonte: Processos de tutela de 1900 a 1927 depositados no APERS.

Acreditamos que esse número ligeiramente superior não se deu de forma fortuita. Em 1920, havia no município de Porto Alegre 39.757 meninos de $0-20$ anos contra 42.586 meninas de mesma idade. ${ }^{37} \mathrm{Se}$ as mulheres adultas 
eram, como vimos, muito depreciadas para o cargo de tutor de uma criança ou adolescente no início do século XX, as menores de idade chegam a se sobrepor aos meninos por conta, talvez, da concepção de que deveriam ficar “... resguardadas em casa, se ocupando dos afazeres domésticos, enquanto os homens asseguravam o sustento da família trabalhando no espaço da rua" ${ }^{38}$; assim, não se desvirtuariam ou se mostrariam ao espaço público correndo o risco de serem influenciadas por ele e, assim, corrompidas. ${ }^{39}$ Embora essa não fosse a prática fiel, tendo em vista que muitas mulheres trabalhavam fora do espaço privado - a casa -, os suplicantes a tutor valorizavam esse tipo de moralidade em suas petições, bem como os juristas que avaliavam os casos.

Mesmo com essas restrições algumas mães conseguiram encontrar uma "brecha na lei" para continuar com sua prole. Como foi o caso da menor E. de A. M. ${ }^{40}$

Esse caso exemplifica a exceção entre outros desse período. Nessa ação, sua mãe A. B. de A., viúva do alferes E. E. M., pede ao Juiz H. T. que dê um tutor para sua filha, pois ela, A. B. de A., havia contraído segundas núpcias. Essa era a determinação da lei e, segundo a legislação, perderiam o direito da Tutela as mães e avós que, como vimos, se casassem novamente ou que deixassem de viver "honestamente". Nesses casos, essas mulheres não poderiam reaver a tutela ainda que enviuvassem novamente. ${ }^{41}$

Ao se casar em segundas núpcias, portanto, A. B. de A., perdia o pátrio poder sobre a filha. Nessa contingência, ela, como mãe da menina, indicou um familiar para desempenhar o papel de tutor e, quem sabe, dessa forma, ela não perderia contato com a menor e nem esta perderia a referência familiar. Assim, indicou seu irmão, casado, O. B. de A. Uma estratégia legal encontrada por ela para não perder sua filha para outra pessoa alheia a família.

Mesmo havendo essa possibilidade, muitas mulheres tiveram dificuldades de manter sua prole consigo.

A situação de crise da estrutura familiar é notória em 185 situações que estão relacionadas exclusivamente à figura feminina, seja pelo motivo de que a "mãe tem que se retirar da cidade ou se retirou", seja pela "doença da mãe", fica presente a possibilidade de essas mulheres estarem sozinhas a cuidar de seus filhos, sem a presença do marido ou mesmo de outro familiar que pudesse acautelar a criança, mesmo que informalmente.

A mulher pobre, cercada por uma moralidade oficial completamente desligada de sua realidade, vivia entre a cruz e a espada. O salário minguado e regular de seu marido chegaria a suprir as necessidades domésticas só por um milagre. Mas a dona de casa, que tentava escapar à miséria por seu próprio trabalho, arriscava o pejo da 'mulher pública'. ${ }^{42}$ 
A mulher, como afirma Cláudia Fonseca, estava entre a "cruz e a espada", teria que se ajustar às condições impostas pela sociedade, mesmo que isso significasse passar por adversidades econômicas. Contudo, se as necessidades fossem maiores que as possibilidades de suportar as adversidades, ela tinha que procurar novas formas para sobreviver, mesmo que isso significasse ser qualificada como "mulher da vida" ou "mulher pública", rótulos atribuídos pela sociedade por ela ter que ir trabalhar fora do espaço doméstico e, assim, estar mais sujeita ao assédio moral e sexual e também de receber a alcunha de ser mãe descuidada para com os filhos. Magareth Rago, estudando os códigos de sexualidade feminina em São Paulo, em especial o da prostituição, na República Velha, verificou que a figura da prostituta, antítese da mulher idealizada, permeava o imaginário social da época como a figura perturbadora da ordem social e da família. A mulher era, constantemente, vigiada pelo olhar da sociedade; ela deveria, permanentemente, manter-se policiada em relação a suas ações para que estas não fossem vistas como comportamentos desviantes da moralidade, pois
o homem no espaço público foi sempre percebido positivamente, através da imagem do homem trabalhador e do político, segundo o ideário liberal. A mulher fora do lar, sobretudo se desacompanhada, precisou prestar muita atenção aos seus gestos, aparência, roupas, para não ser confundida com a figura dissoluta, excêntrica da prostituta, 'mulher pública'. ${ }^{43}$

A figura masculina possuía grande respaldo social para viver, mesmo que sozinho, com os filhos, pois, em 73 situações, o motivo elencado nos processos de tutela referia-se diretamente a uma dificuldade relacionada à figura masculina, fosse ela "incapacidade moral do pai" ou o "descaso do pai", número inferior aos diretamente relacionados a questões afeitas à figura feminina. A mulher, na maioria das vezes desamparada pela figura masculina, talvez escolhesse dar seu filho para outra pessoa cuidar, diante da possibilidade de o pequeno vir a ter que enfrentar toda a censura que a mãe possivelmente receberia por ter que ir trabalhar fora do lar. Mesmo nas situações em que ela estabelecia uma nova união matrimonial, escolhia, muitas vezes, apartar-se do pátrio poder sobre os filhos para evitar que o julgamento social se impusesse também sobre a pequena criança.

Contudo, não se pode imaginar que somente as mulheres sofriam com as vicissitudes da vida - ainda que houvesse discriminação quanto à mulher que trabalhasse fora e que o peso maior recaísse sobre seus ombros -, pois os homens também estavam a enfrentar dificuldades, nos anos iniciais do século XX, como se pode constatar no processo da menor P. da S. M..$^{44}$, de 15 anos de 
idade, em que seu pai L. da S. M. pede que sua tutela fosse dada à sua sogra. L. M. afirma que a filha fora criada

desde sua tenra infância por sua avó B. A. R., sogra d'ele suplicante, em cuja companhia vive até hoje. E como não possa o supl.[Suplicante] pelos seus minguados recursos, atender à manutenção d'aquela sua filha e à administração de sua pessoa e bens, vem declarar a V.S. que renuncia ao pátrio poder que lhe assiste e indica a V.S. para exercer a tutela de sua filha a referida sua sogra. ${ }^{45}$

O próprio pai pedia a renúncia do pátrio poder sobre sua filha, por não conseguir subsídios suficientes para prover o alimento, a saúde, educação e o vestuário dele e de sua filha, que já morava com a avó. $O$ pai não podia ser considerado um "vagabundo", pois o processo informa que ele trabalhava, talvez como jornaleiro, mas não tinha uma atividade que lhe possibilitasse arcar com o sustento de ambos.

Os apelos à moralidade e à honra da família eram constantes nos processos de tutela, mas esses eram acionados com maior frequência para questões envolvendo as mulheres, adolescentes e meninas, como no auto da menor, púbere, G. C. da S. ${ }^{46}$ que foi movido tendo por motivo a honra sexual da menor. A própria menor foi ao Juizado de Órfãos dizendo ser órfã de pai e mãe e "tendo sido deflorada ${ }^{47}$, a fim de poder casar-se pede a V [Vossa] S [Senhoria] para nomear tutor" ${ }^{48}$ Seu pedido fora-lhe deferido, no dia seguinte, e nomeado o senhor B. C. da S. como tutor. Dessa forma, surgia um novo arranjo familiar com a chancela da Justiça.

Processos, em que a alegação principal para se conseguir um tutor era a de a menor ter sido deflorada, eram recorrentes no Juízo dos Órfãos. Geralmente, a solicitação vinha acompanhada do pedido para casar-se com o deflorador. O casamento era um valor cultivado pelos grupos dirigentes, mas, entre os populares, como Silvia Arend ${ }^{49}$ já apontou, ele não era uma obrigação: os populares reivindicavam e recorriam a essa união legal em situações pontuais. Esse pedido de tutela, que dava licença para casar-se, podia ter algumas razões por parte da menor como

[...] responsabilizar o amante por uma gravidez que, assumida sozinha, traria maiores dificuldades na luta pela sobrevivência; desejando realizar um casamento proibido pelas famílias; sendo pressionadas pelos patrões ou pela polícia; tentando não perder um 'bom' partido ou mesmo uma paixão. ${ }^{50}$ 
Diferentemente dos processos crimes investigados por Carlos Eduardo Grosso $^{51}$, também para a cidade de Porto Alegre em período semelhante, em que o autor evidenciou que os casos de defloramento eram levados à Justiça Criminal não com a finalidade do casamento legal; os autos judiciais de tutela revelam justamente o oposto, que havia o desejo de uma solução legal para o fato: o casamento. Dessa forma, podemos aventar que a expectativa pelo casamento nos casos de defloramento na cidade de Porto Alegre, nos anos iniciais do século XX, era uma realidade, bem como uma possibilidade que permeava a cabeça não só dos juristas como também das mulheres e da sociedade de forma geral.

Pois, levar a queixa de defloramento de uma menor às autoridades tinha por fim responsabilizar o deflorador pelos seus atos, para que, com base na moralidade da época, houvesse um casamento legal e, assim, a menor "livrarse" da alcunha de "mulher pública", ou mesmo, de mãe solteira. Além disso, também era uma forma legal de isentar o deflorador de responder criminalmente pelos seus atos, por meio do casamento, pois o defloramento era considerado crime pelo Código Penal Brasileiro, Artigo 267..$^{52}$

Esse foi o caso da menor L. F. ${ }^{53}$, filha legítima, com 17 anos de idade, que, assim como no caso anterior, entrou pessoalmente com um processo, no Juízo dos Órfãos, requerendo um tutor que lhe desse a autorização para casar-se com seu deflorador. A menor informou que seu pai, L. F., estava "atualmente em lugar incerto e não sabido" e sua mãe, M. F., morrera havia 4 anos. Assim, a adolescente L. F. pediu à Justiça um tutor que lhe desse "licença para casarse com o Sr. Á. S. que a deflorou e quer reparar o mal pelo casamento. Sendo verdade o que se alega". ${ }^{54}$ A tutela da menor foi deferida ao Sr. R. F. no dia seguinte ao de sua abertura. Podemos perceber, de forma explícita, que o Sr. Á. S. tinha "consciência", e até mesmo a menor L. F., de que a relação sexual que os dois haviam tido se configurava socialmente como "má", e somente o casamento poderia "reparar" isso. O que estava por trás da decisão, de realizarem o casamento entre ambos, não está no processo. Pode-se conjecturar que o motivo poderia estar vinculado a ir contra a vontade dos pais dele ou das pessoas que cuidavam dela, escapar de um processo criminal ou mesmo podese deduzir que a menor o tenha seduzido para "arranjar um casamento", enfim não há certezas; apenas sabe-se que eles haviam reivindicado uma definição de honra que a sociedade da época valorizava: a união por meio do casamento.

Com essa decisão rápida, por parte do Juiz, podemos perceber como Elisabete Leal, estudando os discursos do jornal A Federação $o^{55}$ na virada do século, constatou que a família era o centro das atenções do Partido Republicano Rio-grandense (PRR) nessa sociedade desejosa da modernidade, pois,

é nela que se desenvolvem os sentimentos de sociabilidade, resultando no aperfeiçoamento humano para o viver coletivo. [...] Assim, somente em uma família legalmente 
construída através do casamento, haverá ambiente próprio para o desenvolvimento moral do indivíduo. A união matrimonial é o princípio gerador da família. ${ }^{56}$

O propósito da Justiça em realizar, de forma rápida, a concessão de tutor com a finalidade de este dar permissão para uma menor se casar, era o de civilizar a sociedade, evitando relações de amasiamento, o aparecimento de mães solteiras ou mesmo a possibilidade de essas menores entrarem no meretrício. Assim, civilizar os hábitos da população “....seria o sentido último da possibilidade de a Justiça intervir diretamente nos crimes de defloramento e estupro, com o intuito de estabelecer a ordem moral". ${ }^{57}$ Assim, podemos perceber que recorrer ao Juízo dos Órfãos ao invés da Justiça Criminal, para resolver contendas relativas ao defloramento de uma menor de idade, poderia significar justamente a enfática vontade de se realizar um casamento, já que os Juízes e Curadores Gerais de Órfãos não indeferiam o pedido de tutoria com a finalidade de autorização para casamento ou mesmo de Licença para Casamento ${ }^{58}$ a um menor. Acrescentemos ainda a possibilidade de o casamento estar praticamente acertado, fato que levava as menores a recorrerem ao Juízo dos Órfãos ao invés da Justiça Criminal, com o afinco de encurtar o caminho ao altar. No entanto, não tivemos condições de investigar os registros de casamento do período, documentos que poderiam revelar se houve ou não o casamento, mesmo assim, o fato da menor desejar receber um tutor que permitisse o enlace matrimonial, já é um relevante indício de que o casamento poderia ser um objetivo e uma realidade para as menores de idade.

\section{CONCLUSÃO}

Nestas breves palavras, fica explicita a linha tênue em que a mulher estava perante a sociedade e a Justiça quando procurava pleitear a guarda de um menor de idade, mesmo este sendo seu filho ou neto. Seja na avaliação dos grupos dirigentes, seja na jurisprudência, as mulheres eram consideradas "incapazes", na maioria das vezes, precisando de um responsável do sexo masculino para si. As avós, quando viúvas, tinham certa facilidade para conseguir a guarda de um menor, pois a idade avançada e a maior possibilidade destas não se exporem aos "perigos" morais (como terem novos relacionamentos amorosos) respaldaria a tutoria para elas. Quanto às menores de idade, que foram relativamente mais tuteladas que os meninos, os processos de tutela revelam a grande atenção que os adultos tinham para com as meninas e adolescentes. Tendo um olhar vigilante sobre elas, a "sociedade" enfrentaria menos risco dessas se desvirtuarem-se da moralidade burguesa corrente, atribuindo um tutor de forma rápida poderia livrar as menores desse risco. Dessa forma, verificamos que o Juízo dos Órfãos de Porto Alegre realizou sua ação de zelar pelas meninas e adolescentes, 
depreciando, por outro lado, as mulheres adultas como possíveis tutoras de crianças e adolescentes no início do século XX. Os papéis sexuais socialmente construídos e a relação de poder a que estava submetida à mulher na sociedade adentraram pelas portas do Judiciário através dos operadores do direito que reproduziam a moralidade vigente em suas decisões sempre respaldadas pela legislação e pela jurisprudência, que ratificavam a conduta de favorecimento aos homens na guarda de uma criança ou adolescente.

\section{NOTAS}

$1 \mathrm{O}$ autor agradece aos pareceristas $a d$ hoc da revista Esboços pela generosa contribuição à qualificação do texto.

2 No período compreendido neste texto, início do século XX, o termo menor de idade referiase a todos os indivíduos menores de 21 anos de idade; não tendo a conotação pejorativa que o restante do século XX daria a ele.

3 CARDOZO, José Carlos da Silva. O melhor para quem? O Juizado de Órfãos e o discurso de valorização e proteção aos menores de idade no início do século XX. Tempo e Argumento, UDESC. v. 3, n. 2, p. 210-229, 2011. CARDOZO, José Carlos da Silva. O Juizado de Órfãos de Porto Alegre: um reflexo da sociedade. In: APERS. VIII Mostra de Pesquisa do Arquivo Público do Estado do Rio Grande do Sul. Porto Alegre: Corag, 2010. p. 39-52.

${ }^{4}$ Compreendemos poder como a criação de efeitos causais, bem como o seu uso intencional para afetar a conduta de alguém.

5 O gênero como categoria de análise é utilizado na história para identificar a articulação entre as relações sociais, culturais e de poder não restritas apenas aos determinismos biológicos dos indivíduos. Ver: SCOTT, Joan. Gênero: uma categoria útil de análise histórica. Educação \& Realidade, v. 20, n. 2, p. 71-99, 1995. SOIHET, Rachel; PEDRO, Joana Maria. A emergência da pesquisa da História das Mulheres e das Relações de Gênero. Revista Brasileira de História, v. 27, n. 54, p. 281-300, 2007. PEDRO, Joana Maria. Traduzindo o debate: o uso da categoria gênero na pesquisa histórica. História, São Paulo, v. 24, n.1, p.77-98, 2005. SOIHET, Rachel. História das mulheres. In: CARDOSO, Ciro Flamarion S.; VAINFAS, Ronaldo. (Org.). Domínios da história: ensaios de teoria e metodologia. Rio de Janeiro: Campus, 1997. p. 275-296. TILLY, Louise. Gênero, história das mulheres e história social. Cadernos Pagu, UNICAMP, n. 3, p. 29-62, 1994.

${ }^{6}$ Compreendemos que a tutela era um encargo conferido pelo Juiz de Órfãos a uma pessoa para que gerenciasse os bens e cuidasse da integridade física de um menor de idade, representando-o tanto em juízo como fora dele. Isso ocorria quando uma criança era órfã de pai ou este era ausente, "vagabundo" ou dado a vícios; o Juiz de Órfãos nomeava um tutor para cuidar da criança, exceto quando não houvesse algum nome indicado em testamento. Acontecendo mesmo que o menor tivesse ou vivesse com a mãe, pois esta era, geralmente, considerada impedida de assumir a responsabilidade jurídica de seus filhos se tivesse que trabalhar na via pública ou se casasse novamente.

7 O Juízo dos Órfãos foi criado pelas Ordenações Manuelinas, de existência curtíssima. Foi somente com as Ordenações Filipinas que suas funções e estrutura foram reguladas. 
${ }^{8}$ Sobre a lei do Ventre Livre e a tutela de ingênuos na cidade de Porto Alegre ver: CARDOZO, José Carlos da Silva. A tutela dos filhos de escravas em Porto Alegre. Revista Latino-Americana de História, v. 1, n. 3, p.88-98, 2012.

9 Maiores informações, ver: MOREIRA, Paulo Roberto Staudt. Entre o deboche e a rapina: os cenários sociais da criminalidade popular em Porto Alegre. Porto Alegre: Armazém Digital, 2009. CHALHOUB, Sidney. Trabalho, lar e botequim: o cotidiano dos trabalhadores no Rio de Janeiro da Belle Époque. 2. ed. Campinas/SP: Editora da Unicamp, 2008.

${ }^{10}$ Neste texto não apresentaremos os nomes das partes envolvidas, apenas as iniciais deles.

${ }^{11}$ RIO GRANDE DO SUL. Juízo Districtal da Vara de Orphãos de Porto Alegre. $3^{\text {a }}$ Vara. Entrega de Menor. Proc. $n^{\circ} 1051$ de 1915. [manuscrito]. Porto Alegre, 1915. APERS.

${ }^{12}$ RIO GRANDE DO SUL. Juízo Districtal da Vara de Orphãos de Porto Alegre. $3^{\text {a }}$ Vara. Entrega de Menor. Proc. $n^{\circ} 1051$ de 1915. [manuscrito]. Porto Alegre, 1915. APERS. f. 2.

${ }^{13}$ Foi uma rua em que moravam populares; suas casas eram construídas à margem do Riacho, quase sem quintal. Ver: FRANCO, Sérgio da Costa. Porto Alegre: guia histórico. 4. ed. Porto Alegre: Editora da UFRGS, 2006.

${ }^{14}$ Ato de falar ou tomar ciência do conteúdo de um processo. SANTOS, Washington dos. Dicionário jurídico brasileiro. Belo Horizonte: Del Rey, 2001. p. 246.

${ }^{15}$ Promotor Público do Juízo dos Órfãos.

${ }^{16}$ Litígio, segundo o dicionário jurídico, é a "demanda, disputa; pendência, contenda... O litígio somente terá início quando a parte contesta o pedido do autor". SANTOS, Washington dos. Dicionário jurídico brasileiro. Belo Horizonte: Del Rey, 2001. p. 153.

${ }^{17}$ RIO GRANDE DO SUL. Juízo Districtal da Vara de Orphãos de Porto Alegre. $3^{\text {a }}$ Vara. Entrega de Menor. Proc. $n^{\circ} 1051$ de 1915. [manuscrito]. Porto Alegre, 1915. APERS. f. 6.

${ }^{18}$ RIO GRANDE DO SUL. Juízo Districtal da Vara de Orphãos de Porto Alegre. $3^{\text {a }}$ Vara. Apreensão de Menor. Proc. $n^{\circ} 1053$ de 1916. [manuscrito]. Porto Alegre, 1916. APERS.

${ }^{19}$ A rua, como o longo perímetro da antiga Chácara da Baronesa de Gravataí, foi, por muitos anos, a moradia de famílias populares; essa rua seguiu o caminho humilde do Areal da Baronesa até que os trabalhos de modernização (urbanização, calçamento e canalização do Riacho) a melhorassem, por volta de 1950. Ver: FRANCO, Sérgio da Costa. Porto Alegre: guia histórico. 4. ed. Porto Alegre: Editora da UFRGS, 2006.

${ }^{20}$ RIO GRANDE DO SUL. Juízo Districtal da Vara de Orphãos de Porto Alegre. $3^{\text {a }}$ Vara. Apreensão de Menor. Proc. $n^{\circ} 1053$ de 1916. [manuscrito]. Porto Alegre, 1916. APERS. f. 2.

${ }^{21}$ RIO GRANDE DO SUL. Juízo Districtal da Vara de Orphãos de Porto Alegre. $3^{\text {a }}$ Vara. Apreensão de Menor. Proc. $n^{\circ} 1053$ de 1916. [manuscrito]. Porto Alegre, 1916. APERS. f. 2v.

${ }^{22}$ RIO GRANDE DO SUL. Juízo Districtal da Vara de Orphãos de Porto Alegre. $3^{\text {a }}$ Vara. Apreensão de Menor. Proc. $n^{\circ} 1053$ de 1916. [manuscrito]. Porto Alegre, 1916. APERS. f. 6.

${ }^{23}$ Sublinhado como no original.

${ }^{24}$ RIO GRANDE DO SUL. Juízo Districtal da Vara de Orphãos de Porto Alegre. $3^{\text {a }}$ Vara. Apreensão de Menor. Proc. $n^{\circ} 1053$ de 1916. [manuscrito]. Porto Alegre, 1916. APERS. f. 7.

${ }^{25}$ Corresponde a totalidade de autos judiciais abertos na cidade neste período.

${ }^{26}$ CARDOZO, José Carlos da Silva. O Juízo dos Órfãos e a organização da família por meio da tutela. História Social, UNICAMP, n. 20, p. 201-220, 2011. 
${ }^{27}$ SCOTT, Ana Silvia Volpi; BASSANEZI, Maria Silvia C. No fundo do baú: procurando as crianças imigrantes nas fontes documentais paulistas. In: RADIN, José Carlos (Org.). Cultura e identidade italiana no Brasil. Joaçaba: UNOESC, 2005. p. 175.

${ }^{28}$ FUNDAÇÃO DE ECONOMIA E ESTATÍSTICA. De província de São Pedro a Estado do Rio Grande do Sul - censos do RS (1803-1950). Porto Alegre: FEE, 1981.

${ }^{29}$ Em estudo anterior, verificamos que alguns indivíduos solicitavam a guarda de um menor com a finalidade de colocá-lo em alguma atividade laboral. Situação muitas vezes aceita pelos operadores do direito por entenderem que o trabalho permitiria a constituição de um cidadão afeito ao trabalho, com amor pela família e livre dos vícios e doenças. Ver: CARDOZO, José Carlos da Silva. O Juizado de Órfãos de Porto Alegre e a tutela de menores: a formação do futuro cidadão através do trabalho. Aedos, UFRGS, v. 2, n. 4, p. 146-156, 2009.

${ }^{30}$ FONSECA, Cláudia. Ser mulher, mãe e pobre. In: DEL PRIORE, Mary (Org.); BASSANEZI, Carla (Coord. de Textos). História das mulheres no Brasil. 9. ed. São Paulo: Contexto, 2008. p. 526 .

${ }^{31}$ ALMEIDA, Cândido Mendes de. Código Filipino ou Ordenações e leis do Reino de Portugal, recompiladas por mandado do rei D. Philippe I. 14. ed. Rio de Janeiro: Tipografia do Instituto Philomathico, 1870, liv. $4^{\circ}$, tit. $102 \S 4$.

${ }^{32}$ ALVES, João Luiz. Código Civil: da República dos Estados Unidos do Brasil: promulgado pela Lei n. 3071, de 1 de janeiro de 1916. Rio de Janeiro: F. Briguiet, 1917.

${ }^{33}$ RIO GRANDE DO SUL. Juízo Districtal da Vara de Orphãos de Porto Alegre. 1 ${ }^{\text {a }}$ Vara. Tutela. Proc. $n^{\circ} 390$ de 1923. [manuscrito]. Porto Alegre, 1923. APERS.

${ }^{34}$ A Lei do Velleano era um benefício dado às mulheres em que elas não poderiam ser fiadoras e nem obrigadas por outros a serem. A renúncia era fundamental, pois, se o menor possuísse bens, a avó deveria, como todo o tutor de menor, realizar depósito no Cofre dos Órfãos como forma de garantia; caso utilizasse de forma imprópria os bens ou rendimentos do menor, este estaria com uma reserva no Cofre dos Órfãos quando atingisse a maioridade; ou, mesmo que o menor não possuísse bens, ela deveria estar apta a ser em razão de alguma necessidade do menor.

${ }^{35}$ RIO GRANDE DO SUL. Juízo Districtal da Vara de Orphãos de Porto Alegre. $2^{\text {a }}$ Vara. Tutela. Proc. $n^{\circ} 621$ de 1925. [manuscrito]. Porto Alegre, 1925. APERS.

${ }^{36}$ RIO GRANDE DO SUL. Juízo Districtal da Vara de Orphãos de Porto Alegre. $3^{\text {a }}$ Vara. Tutela. Proc. n. 583 de 1910. [manuscrito]. Porto Alegre, 1910. APERS.

${ }^{37}$ FUNDAÇÃO DE ECONOMIA E ESTATÍSTICA, op. cit.

${ }^{38}$ FONSECA, op. cit., p. 517.

${ }^{39}$ ESTEVES, Martha Abreu. Meninas perdidas: os populares e o cotidiano do amor no Rio de Janeiro da Belle Époque. Rio de Janeiro: Paz e Terra, 1989.

${ }^{40}$ RIO GRANDE DO SUL. Juízo Districtal da Vara de Orphãos de Porto Alegre. 2a Vara. Tutela. Proc. $n^{\circ} 611$ de 1915. [manuscrito]. Porto Alegre, 1915. APERS.

${ }^{41}$ ALMEIDA, Cândido Mendes de. Código Filipino ou Ordenações e leis do Reino de Portugal, recompiladas por mandado do rei $D$. Philippe I. 14. ed. Rio de Janeiro: Tipografia do Instituto Philomathico, 1870, liv. $4^{\circ}$, tit. $102 \S 4$.

${ }^{42}$ FONSECA, op. cit., p. 516. 
${ }^{43}$ RAGO, Margareth. Os prazeres da noite: prostituição e códigos da sexualidade feminina em São Paulo (1890-1930). 2. ed. rev. e ampl. São Paulo: Paz e Terra, 2008, p. 44.

${ }^{44}$ RIO GRANDE DO SUL. Juízo Districtal da Vara de Orphãos de Porto Alegre. $2^{\text {a }}$ Vara. Tutela. Proc. $n^{\circ} 354$ de 1910. [manuscrito]. Porto Alegre, 1910. APERS.

${ }^{45}$ RIO GRANDE DO SUL. Juízo Districtal da Vara de Orphãos de Porto Alegre. $2^{\mathrm{a}}$ Vara. Tutela. Proc. $n^{\circ} 354$ de 1910. [manuscrito]. Porto Alegre, 1910. APERS. f. 2.

${ }^{46}$ RIO GRANDE DO SUL. Juízo Districtal da Vara de Orphãos de Porto Alegre. $1^{a}$ Vara. Tutela. Proc. $n^{\circ} 70$ de 1915. [manuscrito]. Porto Alegre, 1915. APERS.

${ }^{47} \mathrm{O}$ defloramento era a cópula com mulher virgem ocasionando o rompimento do hímen da menor. Se não houvesse a cópula, o crime seria de atentado contra o pudor. A diferença entre defloramento e estupro é que no primeiro haveria o consentimento da menor, por sedução ou mentira da parte do homem; no segundo, não haveria o consentimento e, sim, imposição por violência.

${ }^{48}$ RIO GRANDE DO SUL. Juízo Districtal da Vara de Orphãos de Porto Alegre. $1^{\text {a }}$ Vara. Tutela. Proc. $n^{\circ} 70$ de 1915. [manuscrito]. Porto Alegre, 1915. APERS. f. 2.

${ }^{49}$ AREND, Silvia Maria Fávero. Amasiar ou casar? A família popular no final do século XIX. Porto Alegre: Editora da Universidade/UFRGS, 2001.

${ }^{50}$ ESTEVES, op. cit., p. 203.

${ }^{51}$ GROSSO, Carlos Eduardo Millen. Do crime de defloramento: populares e práticas amorosas (Porto Alegre - 1898/1923). In. APERS. IX Mostra de Pesquisa do Arquivo Público do Estado do Rio Grande do Sul. Porto Alegre: Corag, 2011. p. 197-211.

${ }^{52}$ GAMA, Affonso Dionysio. Código penal brasileiro: (Dec. n. 847, de 11 de outubro de 1890). São Paulo: Saraiva, 1923.

${ }^{53}$ RIO GRANDE DO SUL. Juízo Districtal da Vara de Orphãos de Porto Alegre. $3^{\text {a }}$ Vara. Tutela. Proc. $n^{\circ} 596$ de 1913. [manuscrito]. Porto Alegre, 1913. APERS.

${ }^{54}$ RIO GRANDE DO SUL. Juízo Districtal da Vara de Orphãos de Porto Alegre. $3^{\text {a }}$ Vara. Tutela. Proc. $n^{\circ} 596$ de 1913. [manuscrito]. Porto Alegre, 1913. APERS. f. 2.

${ }_{55}^{5}$ Jornal do PRR e, por conseguinte, do governo que apresentava as ideias e ideologias desse.

${ }^{56}$ LEAL, Elisabete. Mulher e família na virada do século: o discurso d' A Federação. In: HAGEN, Acásia Maria M.; MOREIRA, Paulo Roberto S. (Org.). Sobre a rua e outros lugares: reinventando Porto Alegre. Porto Alegre: Caixa Econômica Federal, 1995. p. 29-30.

${ }^{57}$ ESTEVES, op. cit., p. 83.

${ }^{58}$ Licença para Casamento era outro tipo de processo judicial administrado pelo Juizado de Órfãos com a finalidade de conceder, o próprio Juiz, autorização para a/o menor se casar.

Artigo recebido em maio de 2012. Aceito em abril de 2013. 